\title{
Recurrence or new tumors after complete resection of pheochromocytomas and paragangliomas: a systematic review and meta-analysis
}

\author{
Laurence Amar 1,2,3, *, Charlotte Lussey-Lepoutre ${ }^{2,3, *}$, Jacques W M Lenders ${ }^{4,5}$, \\ Juliette Djadi-Prat ${ }^{6}$, Pierre-Francois Plouin ${ }^{1,2,3}$ and Olivier Steichen ${ }^{7,8,9}$ \\ ${ }^{1}$ Faculty of Medicine, Université Paris-Descartes, Paris, France, ${ }^{2}$ Hypertension Unit, AP-HP, Hôpital \\ Européen Georges Pompidou, Paris, France, ${ }^{3}$ Paris Cardiovascular Research Center, INSERM UMR970, \\ Paris, France, ${ }^{4}$ Department of Internal Medicine, Radboud University Medical Center, Nijmegen, The \\ Netherlands, ${ }^{5}$ Department of Internal Medicine III, Technische Universität Dresden, University Hospital \\ Carl Gustav Carus, Dresden, Germany, ${ }^{6}$ Clinical Research Unit, AP-HP, Hôpital Européen Georges \\ Pompidou, Paris, France, ${ }^{7}$ Faculty of Medicine, Sorbonne Universités, UPMC Univ Paris 06, Paris, France, \\ ${ }^{8}$ INSERM, U1142, LIMICS, Paris, France, and ${ }^{9}$ Department of Internal Medicine, AP-HP, Hôpital Tenon, \\ Paris, France \\ *(L Amar and C Lussey-Lepoutre contributed equally to this work)
}

Correspondence should be addressed to $O$ Steichen

Email

olivier.steichen@aphp.fr

Abstract

Objectives: To systematically review the incidence and factors associated with recurrences or new tumors after apparent complete resection of pheochromocytoma or thoraco-abdomino-pelvic paraganglioma.

Design: A systematic review and meta-analysis of published literature was performed.

Methods: Pubmed and Embase from 1980 to 2012 were searched for studies published in English on patients with non-metastatic pheochromocytoma or thoraco-abdomino-pelvic paraganglioma, complete tumor resection, postoperative follow-up exceeding 1 month, and recurrence or new tumor documented by pathology, hormonal dosages, or imaging tests. Incidence rates of new events after curative surgery were calculated for each study that had sufficient information and pooled using random-effect meta-analysis.

Results: In total, 38 studies were selected from 3518 references, of which 36 reported retrospective cohorts from the USA, Europe, and Asia. Patient follow-up was neither standardized nor exhaustive in the included studies. A clear description of patient retrieval methods was available for nine studies and the follow-up protocol and patient flow for four studies. Only two studies used multivariable methods to assess potential predictors of postoperative events. The overall rate of recurrent disease from 34 studies was 0.98 events $/ 100$ person-years ( $95 \%$ confidence interval $0.71,1.25)$. Syndromic diseases and paragangliomas were consistently associated with a higher risk of a new event in individual studies and in meta-regression analysis.

Conclusions: The risk of recurrent disease after complete resection of pheochromocytoma may be lower than that previously estimated, corresponding to five events for 100 patients followed up for 5 years after complete resection. Risk stratification is required to tailor the follow-up protocol after complete resection of a pheochromocytoma or paraganglioma. Large multicenter studies are needed to this end. 


\section{Introduction}

Pheochromocytomas and paragangliomas ( $\mathrm{PH} / \mathrm{PG})$ are rare neuroendocrine tumors arising from chromaffin cells of the adrenal medulla or sympathetic and parasympathetic paraganglia respectively. Following resection of the primary tumor, most patients are free of tumor with no clinical, biochemical, or imaging evidence of persistent disease. However, tumor-free patients are at a risk of long-term recurrence, defined as the reappearance of disease after complete surgical eradication of the tumor (1). Recurrences may arise at the operated site or may be metastatic, developing in non-chromaffin organs, mainly the lymph nodes, bones, lungs, and liver $(2,3)$. Patients with inherited tumors may also develop new PH/PGs in the contralateral adrenal gland or in other paraganglia $(3,4)$. At least $15 \%$ of patients undergoing surgery for PH/PG develop new tumors or recurrences, most of which are metastatic (4). Consequently, long-term follow-up is recommended for patients who have undergone surgery for PH/PG (5).

Although there are reports of the prognostic value of various clinical, genetic, and pathological features, there are no robust prognostic indices of recurrence other than the higher probability of new events in patients with inherited tumors and possibly in patients with extra-adrenal or large tumors $(4,5)$. The total duration of follow-up that is required remains unclear, as new events may occur decades after initial surgery. The optimal combination and sequence of biochemical and imaging tests to detect and monitor recurrences are poorly defined. There have been no comprehensive systematic reviews assessing the incidence of recurrences or new tumors following surgery for PH/PG.

Our primary objective is to systematically review the incidence of local or metastatic recurrences or new tumors in patients who have undergone apparently complete resection of a non-metastatic $\mathrm{PH} / \mathrm{PG}$. A secondary objective is to assess the factors associated with recurrences (local or metastatic) or new tumors.

\section{Methods}

\section{Eligibility criteria}

We searched randomized or non-randomized controlled trials, prospective or retrospective cohort studies, and case-control studies published in English in 1980 or later (computed tomography and metanephrine determinations were not universally available before 1980). Studies were eligible if (i) they enrolled at least 20 patients with $\mathrm{PH} /$ PG; (ii) patients had reportedly undergone complete tumor resection; (iii) postoperative follow-up exceeded
1 month (arbitrarily); and (iv) the number of patients with recurrence or new tumor could be identified.

\section{Information sources and search}

We searched Medline and Embase databases from $01 / 01 / 1980$ to $10 / 19 / 2012$. We developed a specific search strategy for each database and is presented in Supplementary Methods (see section on supplementary data given at the end of this article).

\section{Study selection}

Two physicians, experts in endocrine hypertension (L A and C L), independently made a first selection using the titles, abstracts, and keywords to exclude studies that clearly did not fulfill the inclusion criteria. They independently read the full text of the remaining papers to identify eligible articles. At each stage, disagreements between readers were resolved by discussion or, if necessary, by a third reader (P F P or J L). Journals and authors were not blinded during study selection. In cases of overlapping publications by a given team, only the most comprehensive or most recent was included.

The studies were then further subdivided into two categories: (i) studies on head and neck paraganglioma only and (ii) studies on pheochromocytoma and thoracoabdomino-pelvic paraganglioma. This review reports only the results of the latter category of studies.

\section{Data collection}

A standardized form was tested on ten articles and two senior experts (P F P and J L) to homogenize further data collection. The form was then used by two abstractors (L A and $\mathrm{C} \mathrm{L}$ ) to extract methodological and clinical data from all included studies. Records were reviewed by a third reader and issues were resolved by discussion. Journals, titles, and authors were not blinded during data abstraction.

The following data were collected from each study: first author and publication year; study design and settings; number of centers, total number and number of operated patients with complete tumor resection; risk of bias; percentage of female patients, mean age, percentage of hypertensive patients, percentage of patients with pheochromocytoma, location of paragangliomas, mean tumor size, percentage of secreting tumors, and percentage of genetic or syndromic diseases; number of patients with follow-up and duration of follow-up; incidence of recurrence, timing of recurrence, and attributable deaths. 


\section{Quality assessment}

No agreed criteria exist for assessing the risk of bias of prognostic studies. We used several resources to compile a list of criteria to assess the risk of bias regarding study participants, prognostic factors, outcome, follow-up, and reporting. Further details are provided in the Supplementary Methods.

\section{Summary measures}

Incidence rates of recurrence or new tumor over the entire duration of the follow-up were calculated by dividing the number of events by the number of person-years of follow-up, and then standardized to the number of events/100 person-years. The mean duration of follow-up was multiplied by the number of patients when the number of person-years of follow-up was not reported. When the mean duration of follow-up was not reported, it was approximated by a formula using the median and range when available $(6,7)$, or by the median in other cases. We assumed the Poisson distribution to estimate 95\% confidence intervals for the rate of events presented in forest plots. Meta-analysis was performed on rates and their confidence interval limits. Heterogeneity was
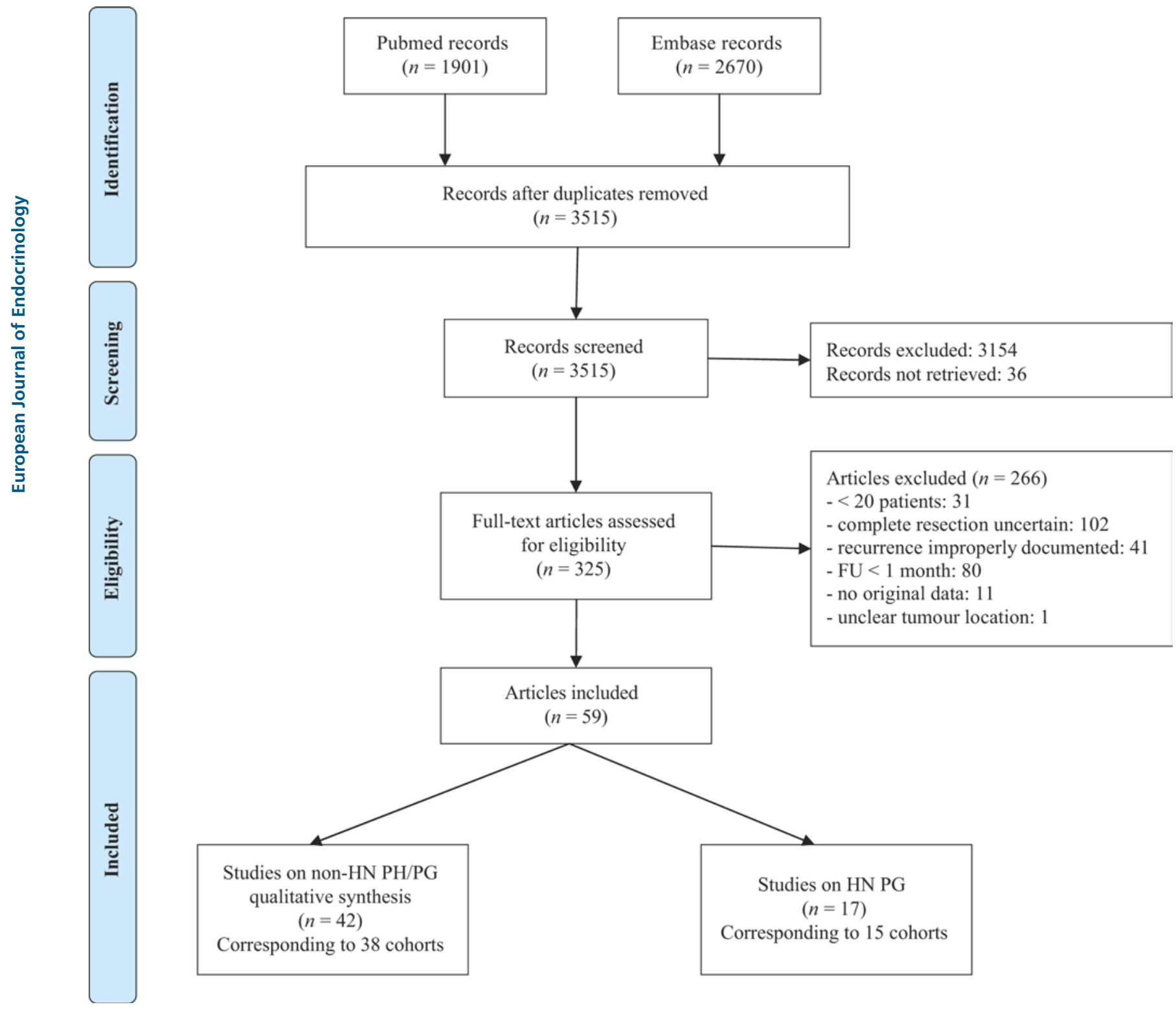

Figure 1

Study flow diagram. FU, follow-up; HN, head and neck; PH/PG, pheochromocytomas and paragangliomas; PG, paragangliomas. 
assessed using Cochran statistic and the $\mathrm{I}^{2}$ inconsistency coefficient. An $\mathrm{I}^{2}$ value greater than $50 \%$ was considered to be indicative of substantial heterogeneity. Study results were pooled using random-effect meta-analysis. We used Stata SE/MP version 9.2 (StataCorp) for the analyses.

\section{Additional analyses}

We performed sensitivity analyses based on the availability of the mean duration of follow-up (allowing to compute the exact incidence rate) and by risk of bias. A funnel plot of the event rate according to the number of person-years of follow-up (a substitute for the precision of estimates) was used to assess publication bias.

Table 1 Overview of included studies.

西

\begin{tabular}{l}
\hline \\
Country \\
\hline India \\
France \\
Ireland \\
USA \\
USA \\
Brazil \\
Italy \\
France \\
USA \\
Sweden \\
Italy \\
UK \\
Israel \\
The Netherlands \\
Finland \\
Italy \\
USA \\
USA \\
Sweden \\
USA \\
China \\
Brazil \\
Italy \\
Germany \\
Japan \\
Japan \\
China \\
Korea \\
Spain \\
Spain \\
The Netherlands \\
USA \\
Suede \\
Italy \\
The Netherlands \\
Ireland \\
USA \\
USA \\
\hline
\end{tabular}

Period

1990-2010

1975-2006

1970-1991

1995-2003

1993-2000

1995-2006

1992-2008

1993-2009

1995-2004

1976-1999

1977-1996

1978-1992

1989-2009

1983-2001

1985-2008

1985-2010

1992-2001

1995-2000

1950-1997

1956-1990

1998-2005

1974-1994

1977-1996

1985-1995

1957-1995

1981-1994

1990-2004

1989-2008

1979-1995

-

1959-2010

1950-1983

1956-1982

2000-2006

1966-2000

1989-2000

1995-2005

1962-2003
Meta-regression analysis was used to assess the impact of the following variables on the logarithm of incidence rates: operation year of the first patient, specialty of the author team (surgery vs others), percentage of females, mean age, percentage of familial diseases (genetic or syndromic), percentage of pheochromocytomas, mean size of the tumor, and mean duration of follow-up.

\section{Results}

\section{Study selection}

The details of the selection process and reasons for exclusions are depicted in the flow chart (Fig. 1). 
Bibliographic searches yielded 3518 references, among which 42 on pheochromocytoma and thoraco-abdominopelvic paraganglioma were finally selected, reporting 38 different cohorts.

\section{Study characteristics}

The characteristics of the included studies are reported in Table 1.
All studies were on retrospective cohorts except one on a prospective cohort (44) and one that was a randomized controlled trial (45). Of the 38 studies, 20 were performed in Europe, nine in North America, six in Asia, two in South America, and one in the Middle East. The inception year ranged from 1950 to 2000 (median 1985). Studies involved 1-21 centers; 20 studies were performed by surgical teams, ten by medical teams, seven by both, and one by laboratory physicians.

Table 2 Overview of patient and disease characteristics.

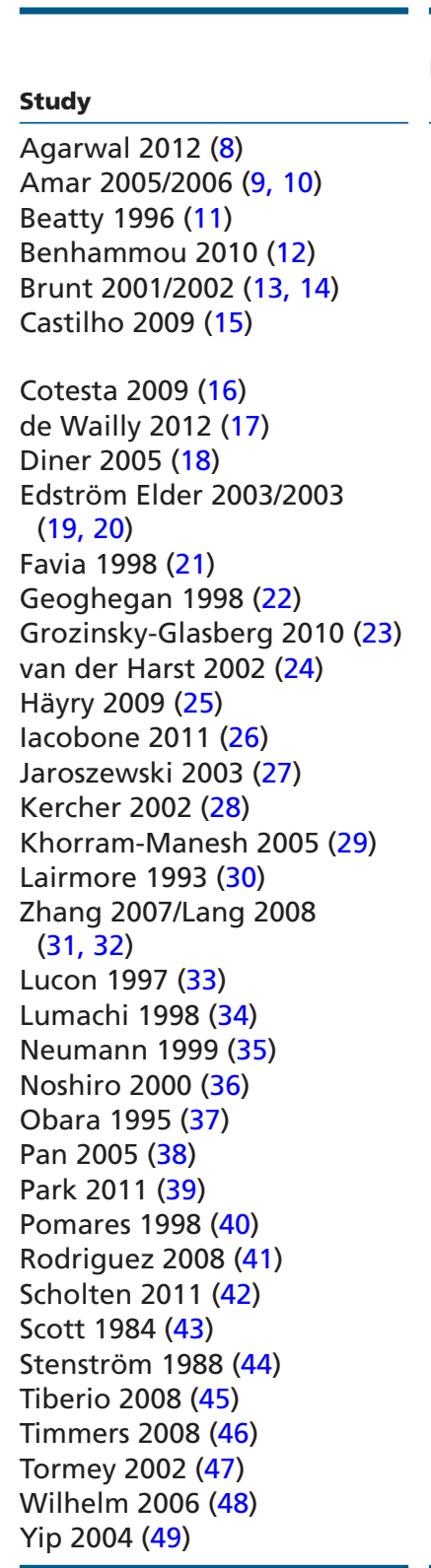

\begin{tabular}{|c|c|}
\hline $\begin{array}{c}\text { Females } \\
(\%)\end{array}$ & Age (years) \\
\hline 43 & Mean 36 (s.D. 14.6) \\
\hline 52 & Mean 42.5 (s.D. 15) \\
\hline 54 & - \\
\hline- & Mean 27 \\
\hline 51 & Mean 42 (s.D. 17) \\
\hline 42 & $\begin{array}{l}\text { Median } 46.5 \text { (range } \\
\text { 10-75) }\end{array}$ \\
\hline 52 & Mean 48 (range 8-77) \\
\hline 55 & Mean 53 (range 13-88) \\
\hline- & Mean 38 (range $10-79)$ \\
\hline 56 & Range $14-77$ \\
\hline 49 & Median 41 (range 10-63) \\
\hline 67 & Mean 42 (range $16-73$ ) \\
\hline 49 & Mean 52.6 (range 16-77) \\
\hline 55 & Mean 46 (range 9-78) \\
\hline- & Mean 46.5 \\
\hline 52 & Mean 44.8 (range 15-80) \\
\hline 51 & Mean 53.1 (range 16-81) \\
\hline 64 & Mean 43 (range 19-59) \\
\hline 56 & Mean 47.2 (s.D. 16.8) \\
\hline 57 & Mean 32.8 (s.D. 12.2) \\
\hline 49 & Mean 35.8 (s.D. 13.3) \\
\hline 56 & Median 33 (range 10-64) \\
\hline 49 & Mean 41 (range $10-63$ ) \\
\hline 59 & Mean 40 (range $10-76$ ) \\
\hline 55 & Mean 40 (s.D. 14) \\
\hline 56 & Median 40 (range 11-67) \\
\hline 58 & Mean 39.5 (s.D. 8.9) \\
\hline 47 & Mean 46.5 (range 18-76) \\
\hline 54 & Mean 43 (s.D. 13.7) \\
\hline 57 & Mean 37.4 (range 14-71) \\
\hline 39 & Mean 33 (s.D. 12.7) \\
\hline 58 & Range 9-79 \\
\hline 53 & Mean 45 (range 15-79) \\
\hline 36 & Mean 51 (range 34-74) \\
\hline 64 & Mean 46.1 (s.D. 15.6) \\
\hline 38 & Median 36 (range 8-76) \\
\hline 62 & Mean 48.5 (s.D. 16.1) \\
\hline 58 & Median 36 \\
\hline
\end{tabular}

\begin{tabular}{|c|c|c|}
\hline $\begin{array}{l}\text { HTN } \\
(\%)\end{array}$ & $\begin{array}{c}\text { Pheo } \\
(\%)\end{array}$ & PHPG size $(\mathrm{mm})$ \\
\hline 81 & 82 & Mean 71 (s.D. 25) \\
\hline 89 & 87 & Mean 54 (s.D. 27) \\
\hline 90 & 84 & - $\quad$ - n - n \\
\hline- & 100 & Mean 25 \\
\hline 54 & 100 & Mean 34 (s.D. 13) \\
\hline 83 & 100 & Median 37 (range 5-120) \\
\hline- & 92 & Mean 43 (range 10-110) \\
\hline- & 100 & Mean 46 (s.D. 13) \\
\hline- & 100 & Mean 23 (range 8-50) \\
\hline 61 & 82 & Range $10-140$ \\
\hline 58 & 91 & Mean 58 (S.D. 30) \\
\hline 56 & 100 & Mean 49 (range 20-130) \\
\hline 47 & 88 & Mean 49 (s.D. 20) \\
\hline 66 & 89 & Mean 54 (s.D. 31) \\
\hline- & 95 & Mean 47 (s.D. 26) \\
\hline- & 93 & Mean 54 (s.D. 30) \\
\hline- & 100 & Mean 43 (range $10-85$ ) \\
\hline 95 & 97 & Mean 52 (range 20-121) \\
\hline 84 & 93 & Mean 49 (s.D. 24) \\
\hline 57 & 100 & Mean 43 (s.D. 27) \\
\hline- & 100 & Mean 47 (s.D. 23) \\
\hline 86 & 84 & Median 70 (range 30-200) \\
\hline 45 & 90 & - \\
\hline- & 100 & Mean 40 (range 10-90) \\
\hline 88 & - & - \\
\hline- & 84 & Mean 62 (s.D. 26) \\
\hline- & 85 & Mean 73 (s.D. 35) \\
\hline 62 & 90 & Mean 67 (s.D. 35) \\
\hline 37 & 98 & Mean 49 (s.D. 26) \\
\hline 24 & 100 & Mean 45 (range $10-120)$ \\
\hline 3 & 100 & - \\
\hline 98 & 77 & - \\
\hline 47 & 94 & - \\
\hline- & 100 & Mean 40 (range 22-60) \\
\hline 78 & 88 & - \\
\hline 89 & 87 & - \\
\hline 68 & 100 & Mean 40 (s.D. 15) \\
\hline- & 95 & - \\
\hline
\end{tabular}

\begin{tabular}{|c|c|}
\hline $\begin{array}{c}\text { Secreting } \\
\text { tumors } \\
(\%) \\
\end{array}$ & $\begin{array}{c}\text { Genetic } \\
\text { diseases } \\
(\%)\end{array}$ \\
\hline- & - \\
\hline- & 21 \\
\hline- & 24 \\
\hline- & 100 \\
\hline- & 57 \\
\hline- & 13 \\
\hline- & 23 \\
\hline $96^{b}$ & 15 \\
\hline- & 94 \\
\hline- & 18 \\
\hline- & 7 \\
\hline- & 28 \\
\hline- & - \\
\hline- & 31 \\
\hline $86^{c}$ & - \\
\hline- & 24 \\
\hline- & 13 \\
\hline $95^{\mathrm{b}}$ & 10 \\
\hline $88^{b}$ & 25 \\
\hline- & 100 \\
\hline- & - \\
\hline $97^{b}$ & 12 \\
\hline- & 7 \\
\hline- & 67 \\
\hline- & 15 \\
\hline 92 & 14 \\
\hline 0 & - \\
\hline- & 2 \\
\hline $84^{b}$ & 52 \\
\hline 89 & 100 \\
\hline 67 & 100 \\
\hline- & 12 \\
\hline- & 20 \\
\hline- & - \\
\hline- & 20 \\
\hline- & 59 \\
\hline- & 14 \\
\hline- & 97 \\
\hline
\end{tabular}

${ }^{\mathrm{a}} \mathrm{Familial}$ or syndromic disease or germline mutation; ${ }^{\mathrm{b}}$ Methoxylated derivatives only; ${ }^{\mathrm{c} C a l c u l a t e d}$ using urinary normetanephrine + metanephrine: abnormal if $\geq 4.5 \mu \mathrm{mol} / 24 \mathrm{~h}$. 


\section{Risk of bias within studies}

Detailed risks of bias of the included studies are reported in the Supplementary Table 1. Only nine studies explained how they ensured the completeness of patient retrieval (for instance, through a prospectively maintained research database or administrative databases with diagnostic coding). Only four studies provide a clear and specific description of patient flow (inclusion, operation, cure, and follow-up). Fourteen studies looked for prognostic factors, but only two performed multivariate analyses.

\section{Patient and disease characteristics}

Patient and disease characteristics are reported in Table 2. The percentage of females was reported in 35 studies and was between 36 and $67 \%$ (median 54\%). The mean or median age was reported in 35 studies and was between 27 and 53 years (median 42 years). The percentage of hypertensive patients was reported in 25 studies and was between 3 and 98\% (median 66\%). The percentage of syndromic or genetic disease was reported in 32 studies. Of the 32 studies, four involved only patients with a syndromic disease (VHL, NF1, or MEN2). In the

Table 3 Overview of treatment and outcomes.

\begin{tabular}{|c|c|c|c|c|c|c|}
\hline Study & $\begin{array}{l}\text { Cured and } \\
\text { followed up }\end{array}$ & Follow-up duration (months) & $\begin{array}{l}\text { Same-site } \\
\text { recurrences }\end{array}$ & $\begin{array}{l}\text { Other-site } \\
\text { recurrences }\end{array}$ & Metastases & $\begin{array}{l}\text { Attributable } \\
\text { death }\end{array}$ \\
\hline Agarwal 2012 (8) & 100 & Mean 44 (range 3-160) & 0 & 0 & 1 & 0 \\
\hline Amar 2005/2006 $(9,10)$ & 242 & Mean 102 (range 45.6-158.4) & 18 & 0 & 18 & 0 \\
\hline Beatty 1996 (11) & 38 & Mean 84 & 2 & 0 & 4 & 4 \\
\hline Benhammou 2010 (12) & 26 & Mean 111 & 3 & 3 & 0 & 0 \\
\hline Brunt $2001 / 2002(13,14)$ & 34 & Mean 46 (range 2-85) & 0 & 3 & 0 & 0 \\
\hline Castilho 2009 (15) & 24 & Mean 74 (range 18-150) & 0 & 0 & 0 & 0 \\
\hline Cotesta 2009 (16) & 43 & Range 6-192 & 2 & 0 & 1 & 2 \\
\hline de Wailly 2012 (17) & 48 & Mean 86 & 0 & 1 & 1 & 0 \\
\hline Diner 2005 (18) & 33 & Mean 36 (range 3-108) & 2 & 0 & 0 & 0 \\
\hline $\begin{array}{l}\text { Edström Elder } 2003 \\
(19,20)\end{array}$ & 80 & Median 144 & 2 & 0 & 3 & 2 \\
\hline Favia $1998(21)$ & 50 & Mean 88 (range 6-232) & 1 & 1 & 0 & 0 \\
\hline Geoghegan 1998 (22) & 41 & Mean 31 (range 9-120) & 0 & 0 & 0 & 1 \\
\hline $\begin{array}{l}\text { Grozinsky-Glasberg } 2010 \\
\text { (23) }\end{array}$ & 41 & - & 0 & 0 & 0 & 0 \\
\hline van der Harst 2002 (24) & 87 & Median 120 (range 3-192) & 0 & 1 & 14 & 10 \\
\hline Hayry 2009 (25) & 36 & Mean 103 (range 20-284) & 1 & 0 & 3 & 0 \\
\hline lacobone 2011 (26) & 70 & Median 126 (range 6-300) & 2 & 0 & 1 & - \\
\hline Jaroszewski 2003 (27) & 45 & Mean 41 (range 10-89) & 0 & 1 & 0 & 0 \\
\hline Kercher 2002 (28) & 39 & Mean 14 (range 1-40) & 0 & 0 & 0 & 0 \\
\hline Khorram-Manesh 2005 (29) & 121 & Mean 180 & 2 & 1 & 6 & 4 \\
\hline Lairmore 1993 (30) & 55 & Mean 112.8 (range 8.4-342) & 0 & 12 & 0 & 0 \\
\hline $\begin{array}{l}\text { Zhang 2007/Lang } 2008 \\
\quad(31,32)\end{array}$ & 103 & Range 5-36 & 0 & 0 & 0 & 0 \\
\hline Lucon 1997 (33) & 35 & Mean 33 (range 0.33-192) & 0 & 0 & 0 & 0 \\
\hline Lumachi 1998 (34) & 50 & Mean 88.2 (range 6-232) & 1 & 0 & 0 & 0 \\
\hline Neumann 1999 (35) & 33 & Mean 73 (range 16-179) & 1 & 7 & 0 & - \\
\hline Noshiro 2000 (36) & 74 & Mean 117 & 1 & 2 & 5 & 4 \\
\hline Obara 1995 (37) & 83 & Median 58 (range 1-164) & 0 & 4 & 0 & 1 \\
\hline Pan 2005 (38) & 25 & Median 66 (range 24-132) & 0 & 0 & 0 & 0 \\
\hline Park 2011 (39) & 147 & Mean 41.5 (range 0.9-298) & 0 & 0 & 12 & 12 \\
\hline Pomares 1998 (40) & 42 & Mean 96 (range 24-216) & 0 & 0 & 1 & 0 \\
\hline Rodriguez 2008 (41) & 54 & Mean 92.5 (range 12-178) & 0 & 5 & 0 & 0 \\
\hline Scholten 2011 (42) & 61 & Mean 160.8 (range 1.2-501.6) & 3 & 18 & 0 & - \\
\hline Scott $1984(43)$ & 53 & Mean 103 (range 12-348) & 0 & 0 & 5 & 4 \\
\hline Stenström 1988 (44) & 64 & Mean 139.2 (range 12-324) & 0 & 2 & 2 & 0 \\
\hline Tiberio 2008 (45) & 22 & Mean 35 (range 18-84) & 0 & 0 & 0 & 0 \\
\hline Timmers 2008 (46) & 64 & Mean 132 (range 12-456) & 2 & 0 & 7 & 7 \\
\hline Tormey 2002 (47) & 32 & - & 2 & 3 & 0 & 2 \\
\hline Wilhelm 2006 (48) & 46 & Mean 24 (range 1-84) & 1 & 0 & 0 & 0 \\
\hline Yip 2004 (49) & 58 & Median 71 & 7 & 3 & 1 & 0 \\
\hline
\end{tabular}


remaining 28 studies with phenotypic and/or genetic information, a syndromic or familial disease and/or a mutation in a gene predisposing to PH/PG was between 2 and $97 \%$ (median 20\%).

The percentage of pheochromocytoma was reported in 37 studies and was between 77 and 100\% (median $94 \%)$. Of these, 14 studies involved only patients with pheochromocytomas, and the percentage of patients with pheochromocytoma was between 77 and 98\% (median $89 \%)$ in the 23 remaining studies with information on tumor location. The mean or median tumor size was reported in 28 studies and was between 23 and $73 \mathrm{~mm}$ (median $48 \mathrm{~mm}$ ).

\section{Results of individual studies}

Raw results of individual studies are reported in Table 3. The number of patients followed up after complete surgical resection was between 22 and 242 (median 52). The mean or median duration of follow-up was available for 34 studies and was between 14 and 180 months (median 84 months). The percentage of recurrent disease over the entire follow-up was between 1 and 34\% (median $6 \%$ ). Eleven studies (51 events) provided individual data on the time from surgery to recurrent disease, with an overall median time to event of 60 months (range 3-204), and two studies (26 events) provided summary results with median times to event of 17 and 29 months

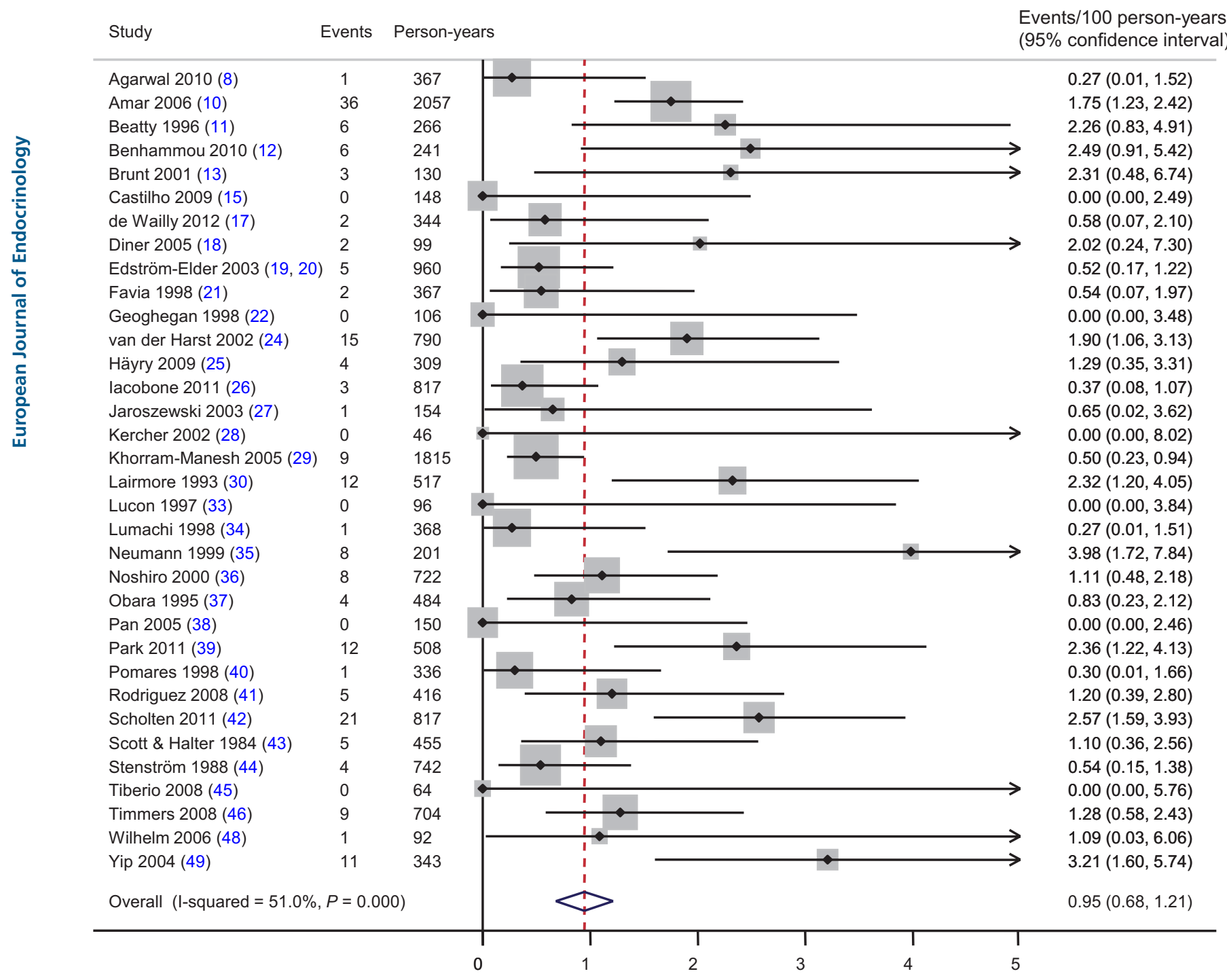

Figure 2

Forest plot of new event rates. 
(range 5-195). Two studies (7 events) did not provide any information on the time to the recurrent event.

Candidate prognostic markers assessed by one or more individual studies are reported in Supplementary Table 2. Paragangliomas (hazard ratios 11 and 8.8 compared with pheochromocytomas) and syndromic diseases (hazard ratios 3.4 and 14 compared with sporadic diseases) were independently associated with an increased risk of a new event after curative surgery in two studies $(9,37)$ and larger tumor size in one study (hazard ratio 1.2 for each supplementary centimeter in tumor diameter) (9). Paragangliomas were also associated with new events by univariate analyses in one additional study but not in two others. Larger tumor size was also associated with an increased risk of a new event by univariate analysis in an additional study but not in three others.

\section{Synthesis of results}

The new event rate estimates of 34 studies with follow-up duration data showed significant heterogeneity (I ${ }^{2} 51 \%$, $P<0.001$; Fig. 2). Random-effect meta-analysis produced an overall new event rate estimate of 0.95 events/100 person-years (95\% confidence interval (CI) 0.68, 1.21). Assuming a steady incidence over time, this converts into a 5-year cumulative incidence of $4.7 \%$ (95\% CI: 3.4, 6.1; Fig. 2), distributed as follows: new tumors $22 \%$, local recurrences $23 \%$, and metastatic recurrences $55 \%$.

The pooled estimate of event rate was as follows:

- 0.98 events/100 person-years (95\% CI: 0.68, 1.29) across studies allowing the calculation of the exact number of person-years of follow-up;

- 1.18 events/100 person-years (95\% CI: 0.71, 1.66) across studies with the lowest risk of bias (at most five risks regarding participants, outcome, follow-up, or results);

- 1.11 events/100 person-years (95\% CI: 0.56, 1.66) across studies fulfilling both conditions.

\section{Risk of bias across studies}

The funnel plot of incidence rate against person-years of follow-up shows that the estimated incidence rate of several studies deviates from the overall estimate (Supplementary Fig. 1).

\section{Meta-regression analysis}

The percentage of genetic or syndromic disease was associated with the rate of new events (Fig. 3 and Supplementary Fig. 2). The pooled event rate estimate was 0.79 events/100 person-years (95\% CI: $0.53,1.04)$ for

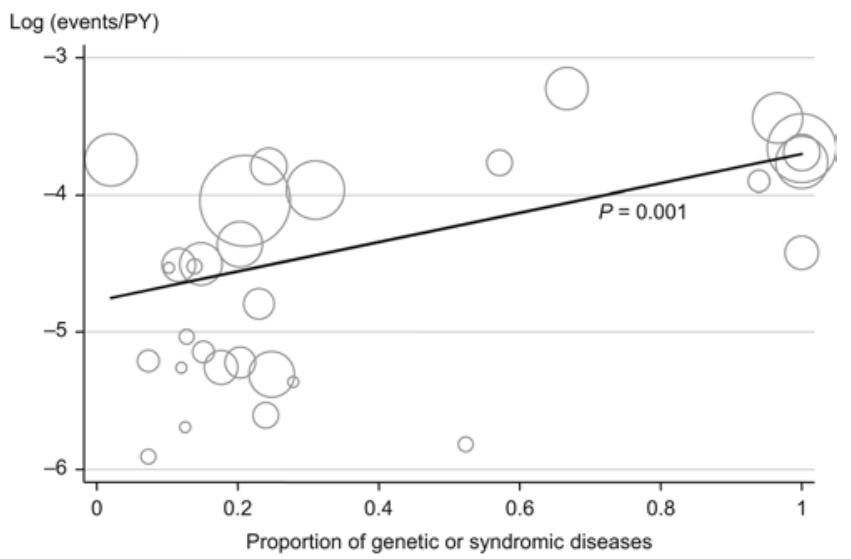

Figure 3

Meta-regression analysis of event rates according to the proportion of genetic or syndromic diseases.

studies with less than $60 \%$ genetic or syndromic diseases ( $\mathrm{I}^{2} 40 \%, P=0.03$ ) and 2.24 events/100 person-years (95\% CI: $1.62,2.87)$ for studies with $60 \%$ or higher genetic or syndromic diseases $\left(\mathrm{I}^{2} 0 \%, P=0.51\right)$. A younger mean age was also associated with a higher rate of new events; however, this association disappeared in a multivariate model including both the mean age and the percentage of genetic or syndromic disease. Other variables were not associated with the new event rate in meta-regression analyses (Supplementary Table 3).

\section{Discussion}

\section{Summary}

Our review suggests that the risk of recurrent disease following complete resection of a pheochromocytoma or a thoraco-abdomino-pelvic paraganglioma is lower than that previously estimated. However, the risk remains nonnegligible, approximately $5 \%$ per 5 years of follow-up, and late events are possible, up to 15 years after surgery in the included studies. Paragangliomas and familial disease are the two main independent risk factors of recurrent disease identified by several studies and by meta-regression analyses across studies. The association between the size of the primary tumor and the risk of recurrence after complete removal was weaker.

\section{Limitations of evidence}

The reporting of methodological details and clinical results of the included studies was very heterogeneous. 
Most studies were retrospective, and patient follow-up was neither standardized nor exhaustive. The time pattern of recurrence risk (early vs late) was not assessed, and data were scarce after the first 10 years of follow-up, precluding any firm conclusion beyond this horizon, although recurrent disease is clearly still possible. Risk factors were not consistently assessed across studies and only a few had available genetic data. It is now estimated that around $40 \%$ of all $\mathrm{PH} / \mathrm{PG}$ arise in patients carrying a germline mutation in one of the 13 susceptibility genes identified so far (50). Individual patient data were not available, and meta-regression analyses were limited by an incomplete description of patients and disease in individual studies.

\section{Implications}

The overall low frequency of recurrent disease after complete resection of a PH/PG calls into question the need for lifelong follow-up after surgery for all patients. This contradicts the estimates from a previous review of published studies that did not take the varying mean duration of follow-up into account (3). Nonetheless, recurrent disease remains possible even after a long and uneventful follow-up and appears to be more frequent in patients with paragangliomas or familial disease than patients with sporadic pheochromocytoma. The follow-up protocol may need to be tailored according to these and other patient and disease characteristics. In particular, several studies that did not meet our inclusion criteria consistently show that germline mutations, even in apparently sporadic cases, are also associated with more aggressive disease and would benefit from intensive follow-up (5).

The results of this systematic review do not allow any conclusion concerning the necessary length and frequency of follow-up after surgery and further research is warranted. Given the rarity of the disease and the number of candidate risk factors, multicenter studies with consistent documentation of the phenotype and genotype of included patients are needed to overcome the limitations of available evidence and reach the power necessary for multivariate prognostic analyses.

\section{Supplementary data}

This is linked to the online version of the paper at http://dx.doi.org/10.1530/ EJE-16-0189.

\section{Declaration of interest}

The authors declare that there is no conflict of interest that could be perceived as prejudicing the impartiality of the research reported.

\section{Funding}

This research was partly funded by the European Society of Endocrinology.

\section{References}

1 Miller AB, Hoogstraten B, Staquet M \& Winkler A. Reporting results of cancer treatment. Cancer 198147 207-214. (doi:10.1002/(ISSN)10970142)

2 DeLellis RA, Lloyd RV, Heitz PU \& Eng C. Pathology and Genetics of Tumours of Endocrine Organs. Lyon, France: IARC, 2004.

3 Amar L, Fassnacht M, Gimenez-Roqueplo A-P, Januszewicz A, Prejbisz A, Timmers H \& Plouin P-F. Long-term postoperative follow-up in patients with apparently benign pheochromocytoma and paraganglioma. Hormone and Metabolic Research 201244 385-389. (doi:10.1055/s-0031-1301339)

4 Plouin P-F, Fitzgerald P, Rich T, Ayala-Ramirez M, Perrier ND, Baudin E \& Jimenez C. Metastatic pheochromocytoma and paraganglioma: focus on therapeutics. Hormone and Metabolic Research 201244 390-399. (doi:10.1055/s-0031-1299707)

5 Lenders JWM, Duh Q-Y, Eisenhofer G, Gimenez-Roqueplo A-P, Grebe SKG, Murad MH, Naruse M, Pacak K, Young WF \& Endocrine Society. Pheochromocytoma and paraganglioma: an endocrine society clinical practice guideline. Journal of Clinical Endocrinology and Metabolism 201499 1915-1942. (doi:10.1210/ jc.2014-1498)

6 Hozo SP, Djulbegovic B \& Hozo I. Estimating the mean and variance from the median, range, and the size of a sample. BMC Medical Research Methodology 20055 13. (doi:10.1186/14712288-5-13)

7 Wan X, Wang W, Liu J \& Tong T. Estimating the sample mean and standard deviation from the sample size, median, range and/or interquartile range. BMC Medical Research Methodology 201414135. (doi:10.1186/1471-2288-14-135)

8 Agarwal G, Sadacharan D, Aggarwal V, Chand G, Mishra A, Agarwal A, Verma AK \& Mishra SK. Surgical management of organ-contained unilateral pheochromocytoma: comparative outcomes of laparoscopic and conventional open surgical procedures in a large singleinstitution series. Langenbeck's Archives of Surgery 2012397 1109-1116. (doi:10.1007/s00423-011-0879-3)

9 Amar L, Servais A, Gimenez-Roqueplo A-P, Zinzindohoue F, Chatellier G \& Plouin P-F. Year of diagnosis, features at presentation, and risk of recurrence in patients with pheochromocytoma or secreting paraganglioma. Journal of Clinical Endocrinology and Metabolism 200590 2110-2116. (doi:10.1210/jc.2004-1398)

10 Amar L, Peyrard S, Rossignol P, Zinzindohoue F, GimenezRoqueplo A-P \& Plouin P-F. Changes in urinary total metanephrine excretion in recurrent and malignant pheochromocytomas and secreting paragangliomas. Annals of the New York Academy of Sciences 20061073 383-391. (doi:10.1196/annals.1353.042)

11 Beatty OL, Russell CF, Kennedy L, Hadden DR, Kennedy TL \& Atkinson AB. Phaeochromocytoma in Northern Ireland: a 21 year review. European Journal of Surgery 1996162 695-702.

12 Benhammou JN, Boris RS, Pacak K, Pinto PA, Linehan WM \& Bratslavsky G. Functional and oncologic outcomes of partial adrenalectomy for pheochromocytoma in patients with von HippelLindau syndrome after at least 5 years of followup. Journal of Urology 2010184 1855-1859. (doi:10.1016/j.juro.2010.06.102)

13 Brunt LM, Moley JF, Doherty GM, Lairmore TC, DeBenedetti MK \& Quasebarth MA. Outcomes analysis in patients undergoing laparoscopic adrenalectomy for hormonally active adrenal tumors. Surgery 2001130 629-634. (doi:10.1067/msy.2001.116920)

14 Brunt LM, Lairmore TC, Doherty GM, Quasebarth MA, DeBenedetti M \& Moley JF. Adrenalectomy for familial pheochromocytoma in the laparoscopic era. Annals of Surgery 2002235 713-720. (doi:10.1097/00000658-200205000-00014) 
15 Castilho LN, Simoes FA, Santos AM, Rodrigues TM \& dos Santos Junior CA. Pheochromocytoma: a long-term follow-up of 24 patients undergoing laparoscopic adrenalectomy. International Brazilian Journal of Urology 200935 24-31. (doi:10.1590/S1677. 55382009000100005

16 Cotesta D, Petramala L, Serra V, Pergolini M, Crescenzi E, Zinnamosca L, De Toma G, Ciardi A, Carbone I, Massa R et al. Clinical experience with pheochromocytoma in a single centre over 16 years. High Blood Pressure \& Cardiovascular Prevention 200916 183-193. (doi:10.2165/11530430-000000000-00000)

17 de Wailly P, Oragano L, Radé F, Beaulieu A, Arnault V, Levillain P \& Kraimps JL. Malignant pheochromocytoma: new malignancy criteria. Langenbeck's Archives of Surgery 2012397 239-246. (doi:10.1007/ s00423-011-0850-3)

18 Diner EK, Franks ME, Behari A, Linehan WM \& Walther MM. Partial adrenalectomy: the National Cancer Institute experience. Urology 200566 19-23. (doi:10.1016/j.urology.2005.01.009)

19 Edström Elder E, Hjelm Skog AL, Hoog A \& Hamberger B. The management of benign and malignant pheochromocytoma and abdominal paraganglioma. European Journal of Surgical Oncology 2003 29 278-283. (doi:10.1053/ejso.2002.1413)

20 Edström Elder E, Xu D, Höög A, Enberg U, Hou M, Pisa P, Gruber A, Larsson C \& Bäckdahl M. KI-67 AND hTERT expression can aid in the distinction between malignant and benign pheochromocytoma and paraganglioma. Modern Pathology 200316 246-255. (doi:10.1097/01. MP.0000056982.07160.E3)

21 Favia G, Lumachi F, Polistina F \& D'Amico DF. Pheochromocytoma a rare cause of hypertension: long-term follow-up of 55 surgically treated patients. World Journal of Surgery 199822 689-693. (doi:10.1007/s002689900454)

22 Geoghegan JG, Emberton M, Bloom SR \& Lynn JA. Changing trends in the management of phaeochromocytoma. British Journal of Surgery $199885117-120$

23 Grozinsky-Glasberg S, Szalat A, Benbassat CA, Gorshtein A, Weinstein R, Hirsch D, Shraga-Slutzky I, Tsvetov G, Gross DJ \& Shimon I. Clinically silent chromaffin-cell tumors: tumor characteristics and long-term prognosis in patients with incidentally discovered pheochromocytomas. Journal of Endocrinological Investigation 201033 739-744. (doi:10.1007/BF03346680)

24 van der Harst E, de Herder WW, de Krijger RR, Bruining HA, Bonjer HJ, Lamberts SWJ, van den Meiracker AH, Stijnen TH \& Boomsma F. The value of plasma markers for the clinical behaviour of phaeochromocytomas. European Journal of Endocrinology $2002 \mathbf{1 4 7}$ 85-94. (doi:10.1530/eje.0.1470085)

25 Häyry V, Salmenkivi K, Arola J, Heikkilä P, Haglund C \& Sariola H. High frequency of SNAIL-expressing cells confirms and predicts metastatic potential of phaeochromocytoma. Endocrine-Related Cancer 200916 1211-1218. (doi:10.1677/ERC-09-0049)

26 Iacobone M, Schiavi F, Bottussi M, Taschin E, Bobisse S, Fassina A, Opocher G \& Favia G. Is genetic screening indicated in apparently sporadic pheochromocytomas and paragangliomas? Surgery 2011150 1194-1201. (doi:10.1016/j.surg.2011.09.024)

27 Jaroszewski DE, Tessier DJ, Schlinkert RT, Grant CS, Thompson GB, van Heerden JA, Farley DR, Smith SL \& Hinder RA. Laparoscopic adrenalectomy for pheochromocytoma. Mayo Clinic Proceedings 2003 78 1501-1504. (doi:10.4065/78.12.1501)

28 Kercher KW, Park A, Matthews BD, Rolband G, Sing RF \& Heniford BT. Laparoscopic adrenalectomy for pheochromocytoma. Surgical Endoscopy 200216 100-102. (doi:10.1007/s00464-001-8171-1)

29 Khorram-Manesh A, Ahlman H, Nilsson O, Friberg P, Odén A, Stenström G, Hansson G, Stenquist O, Wängberg B, Tisell L-E et al. Long-term outcome of a large series of patients surgically treated for pheochromocytoma. Journal of Internal Medicine 2005258 55-66. (doi:10.1111/jim.2005.258.issue-1)

30 Lairmore TC, Ball DW, Baylin SB \& Wells SA. Management of pheochromocytomas in patients with multiple endocrine neoplasia type 2 syndromes. Annals of Surgery 1993217 595-601. (doi:10.1097/00000658-199306000-00001)

31 Zhang X, Lang B, Ouyang J-Z, Fu B, Zhang J, Xu K, Wang B-J

$\&$ Ma X. Retroperitoneoscopic adrenalectomy without previous control of adrenal vein is feasible and safe for pheochromocytoma. Urology 200769 849-853. (doi:10.1016/j. urology.2007.01.078)

32 Lang B, Fu B, OuYang J-Z, Wang B-J, Zhang G-X, Xu K, Zhang J, Wang C, Shi T-P, Zhou H-X et al. Retrospective comparison of retroperitoneoscopic versus open adrenalectomy for pheochromocytoma. Journal of Urology 2008179 57-60. (doi:10.1016/j.juro.2007.08.147)

33 Lucon AM, Pereira MA, Mendonça BB, Halpern A, Wajchenbeg BL \& Arap S. Pheochromocytoma: study of 50 cases. Journal of Urology 1997 157 1208-1212. (doi:10.1016/S0022-5347(01)64925-5)

34 Lumachi F, Polistina F, Favia G \& D'Amico DF. Extraadrenal and multiple pheochromocytomas. Are there really any differences in pathophysiology and outcome? Journal of Experimental \& Clinical Cancer Research 199817 303-305.

35 Neumann HP, Bender BU, Reincke M, Eggstein S, Laubenberger J \& Kirste G. Adrenal-sparing surgery for phaeochromocytoma. British Journal of Surgery 199986 94-97. (doi:10.1046/j.13652168.1999.00974.x)

36 Noshiro T, Shimizu K, Watanabe T, Akama H, Shibukawa S, Miura W, Ito $\mathrm{S} \&$ Miura $\mathrm{Y}$. Changes in clinical features and long-term prognosis in patients with pheochromocytoma. American Journal of Hypertension 200013 35-43. (doi:10.1016/S0895-7061(99)00139-9)

37 Obara T, Kanbe M, Okamoto T, Ito Y, Yamashita T, Ito K, Hirose K, Yamazaki K, Hagihara J \& Kusakabe K. Surgical strategy for pheochromocytoma: emphasis on the pledge of flank extraperitoneal approach in selected patients. Surgery 1995118 1083-1089.

38 Pan D, Li H, Zeng Z, Li F \& Cui Q. Twenty-six patients with nonfunctional pheochromocytomas. Chinese Medical Journal 2005 118 866-868.

39 Park J, Song C, Park M, Yoo S, Park SJ, Hong S, Hong B, Kim C-S \& Ahn H. Predictive characteristics of malignant pheochromocytoma. Korean Journal of Urology 201152 241-246. (doi:10.4111/ kju.2011.52.4.241)

40 Pomares FJ, Cañas R, Rodriguez JM, Hernandez AM, Parrilla P \& Tebar FJ. Differences between sporadic and multiple endocrine neoplasia type 2A phaeochromocytoma. Clinical Endocrinology 1998 48 195-200. (doi:10.1046/j.1365-2265.1998.3751208.x)

41 Rodriguez JM, Balsalobre M, Ponce JL, Ríos A, Torregrosa NM, Tebar J $\&$ Parrilla P. Pheochromocytoma in MEN 2A syndrome. Study of 54 patients. World Journal of Surgery 200832 2520-2526. (doi:10.1007/ s00268-008-9734-2)

42 Scholten A, Valk GD, Ulfman D, Borel Rinkes IHM \& Vriens MR. Unilateral subtotal adrenalectomy for pheochromocytoma in multiple endocrine neoplasia type 2 patients: a feasible surgical strategy. Annals of Surgery 2011254 1022-1027. (doi:10.1097/ SLA.0b013e318237480c)

43 Scott HW \& Halter SA. Oncologic aspects of pheochromocytoma: the importance of follow-up. Surgery 198496 1061-1066.

44 Stenström G, Ernest I \& Tisell LE. Long-term results in 64 patients operated upon for pheochromocytoma. Acta Medica Scandinavica 1988 223 345-352. (doi:10.1111/j.0954-6820.1988.tb15883.x)

45 Tiberio GAM, Baiocchi GL, Arru L, Agabiti Rosei C, De Ponti S, Matheis A, Rizzoni D \& Giulini SM. Prospective randomized comparison of laparoscopic versus open adrenalectomy for sporadic pheochromocytoma. Surgical Endoscopy 200822 1435-1439. (doi:10.1007/s00464-008-9904-1)

46 Timmers HJLM, Brouwers FM, Hermus ARMM, Sweep FCGJ, Verhofstad AAJ, Verbeek ALM, Pacak K \& Lenders JWM. Metastases but not cardiovascular mortality reduces life expectancy following surgical resection of apparently benign pheochromocytoma. Endocrine-Related Cancer 200815 1127-1133. (doi:10.1677/ERC-08-0049) 
47 Tormey WP, Fitzgerald RJ, Davis WG \& Thompson CJ. Twelve-year experience in the investigation and treatment of paragangliomas. International Journal of Clinical Practice 200256 739-745.

48 Wilhelm SM, Prinz RA, Barbu AM, Onders RP \& Solorzano CC. Analysis of large versus small pheochromocytomas: operative approaches and patient outcomes. Surgery 2006140 553-559. (doi:10.1016/j.surg.2006.07.008)
49 Yip L, Lee JE, Shapiro SE, Waguespack SG, Sherman SI, Hoff AO, Gagel RF, Arens JF \& Evans DB. Surgical management of hereditary pheochromocytoma. Journal of the American College of Surgeons 2004198 525-534. (doi:10.1016/j.jamcollsurg.2003.12.001)

50 Favier J, Amar L \& Gimenez-Roqueplo A-P. Paraganglioma and phaeochromocytoma: from genetics to personalized medicine. Nature Reviews Endocrinology 201511 101-111. (doi:10.1038/nrendo.2014.188)

Received 1 March 2016

Revised version received 11 April 2016

Accepted 13 April 2016 